\title{
Bio-efficacy, Persistence and Residual Toxicity of Different Insecticides against Soybean Leaf Miner Aproaerema modicella (Deventer) Infesting Soybean
}

\author{
V. K. Bhamare ${ }^{1 *}$, G. R. Wahekar ${ }^{1}$, D. R. Bankar ${ }^{1}$, B. A. Thakre ${ }^{2}$, \\ P. B. Hajare ${ }^{2}$, R. S. Mahajan ${ }^{2}$ and A. S. More ${ }^{2}$ \\ ${ }^{1}$ Department of Agriculture Entomology, College of Agriculture, Latur (MS)-India \\ ${ }^{2}$ Vasantrao Naik Marathwada Krishi Vidyapeeth, Parbhani (MS)-India \\ *Corresponding author
}

Keywords

Soybean, soybean leaf miner,

Aproaerema modicella

(Deventer), Bio-

efficacy, Residual

toxicity,

Persistence, $\mathrm{LT}_{50}$

Article Info

Accepted:

20 December 2020

Available Online:

10 January 2021
An investigation was undertaken to study the bio-efficacy, persistence and residual toxicity of different insecticides viz., chlorantraniliprole 0.004 per cent, ethion 0.100 per cent, triazophos 0.050 per cent, indoxacarb 0.010 per cent, emamectin benzoate 0.001 per cent, quinalphos 0.050 per cent and profenophos 0.100 per cent against $A$. modicella infesting soybean at the Research Farm of Department of Agril. Entomology, College of Agriculture, Latur (MS). The results proved that all the insecticidal treatments were significantly superior over untreated control in minimizing A. modicella infestation on soybean. Among the treatments, chlorantraniliprole 0.004 per cent was exhibited to be the most effective insecticide in minimizing population of A. modicella on soybean (2.11 larvae per mrl) followed by emamectin benzoate 0.001 per cent (2.67 larvae per mrl), indoxacarb 0.010 per cent (2.89 larvae per mrl), quinalphos 0.050 per cent (3.33 larvae per $\mathrm{mrl}$ ), profenophos 0.100 per cent (3.34 larvae per mrl), ethion 0.100 per cent (4.00 larvae per $\mathrm{mrl}$ ) and triazophos 0.050 per cent (4.22 larvae per $\mathrm{mrl}$ ) after application of insecticides. The highest grain yield was registered by chlorantraniliprole 0.004 per cent (34.87 q per ha) while quinalphos 0.050 per cent (1:19.72) recorded highest incremental cost benefit ratio. The results on residual toxicity of different insecticides against $A$. modicella infesting soybean indicated that chlorantraniliprole 0.004 per cent and emamectin benzoate 0.001 per cent illustrated highest persistent toxicity index (PT) (915.46 and 870.24, respectively) and $\mathrm{LT}_{50}$ values (7.78 and 6.89, respectively) against $A$. modicella after spray as compared to the other insecticides.

\section{Introduction}

Soybean (Glycine max (L.) Merrill) is one of the most important oilseed crops belonging to family Leguminaceae. It is well known as the wonder bean, the miracle golden bean, the pearl of the Orient, the Cinderella crop of the century, the meat that grows on vines, the protein hope of the future and the salvation crop (Lawrence, 2011). It is world's most remarkable seed legume with the unique chemical composition and nutritionally rich in 
energy (446 Kcal), carbohydrates (30.16 g), protein $(36.49 \mathrm{~g})$, fat $(19.34 \mathrm{~g})$, dietary fiber $(9.3 \mathrm{~g})$, ash (4.87 g), various vitamins, electrolytes, minerals, phyto-nutrients (USDA, 2019). Soybean is not only a source of nutrients to human being but also to animals, poultry birds and fishes. The key benefits are related to their excellent protein content (contains all 8 essential amino acids), high levels of essential fatty acids, numerous vitamins and minerals, isoflavones, and fiber (Dwevedi and Kayastha, 2011).

Soybean is instrumental in bringing the yellow revolution. Worldwide, soybean is cultivated on an area of 126.95 million ha with total production of 362.64 million MT and an average productivity of $2860 \mathrm{~kg}$ per ha (USDA, 2020). In India, the area under soybean crop is 11.13 million ha with 13.26 million MT of total production and $1192 \mathrm{~kg}$ per ha of an average productivity (SOPA, 2020). In Maharashtra, soybean is cultivated on area of 0.40 million ha with 0.45 million MT of total production and an average productivity of $1125 \mathrm{~kg}$ per ha (SOPA, 2020).

Despite having made rapid stride for both coverage and total production, soybean still suffers on productivity front (Agarwal et al., 2013). The several biotic and abiotic factors are found responsible for low productivity. Soybean is reported to be attacked by 273 species of insects (Rawat and Kapoor, 1968), amongst 20 insect pest species are significant in India (Singh and Singh, 1990) and 13 in Marathwada region of Maharashtra (Bhamare et al., 2018 and Phatak and Bhamare et al., 2019).

The insect-pest complex of soybean registered 30.8 per cent avoidable seed yield losses (Ahirwar et al., 2014). While, the yield losses ranged from 20 to 100 per cent due to individual disease or insect or weed species (Sharma et al., 2014).
The soybean leaf miner, Aproaerema modicella Deventer (Lepidoptera: Gelichiidae) is one of the most important devastating oligophagous pests of soybean, groundnut and some weeds in the peninsular India. This species is widely distributed in south and south-east Asia. In early stage of the crop growth, leaf miner larvae initially mine into the leaflets, feed on the mesophyll and form small brown blotches on the leaf. Afterward larvae web the leaflets together and feed on them, remaining within the folds (Kolhe et al., 2015). Heavy infestations cause subsequent loss of leaves which in turn reduces the photosynthetically active area leading to yield loss (Du Plessis and Van Denberg, 2011). Leaf miner causes 30-50 per cent losses in grain yield and 75 per cent loss in the leaflets (Shetgar and Thombre, 1984 and; Shirale et al., 2010).

The insecticides are the first option that farmers choose for the control of insect-pests infesting soybean in India and hence several chemical insecticides have been recommended by $\mathrm{CIB}$ and RC. However, these label claimed insecticides need to be revalidated periodically for the effective management of $A$. modicella infesting soybean. In addition, the residual toxicity resulting from foliar application of insecticides could be of great significance in indicating an effective periods over which an insecticide could persist in biologically active stage under field conditions.

The duration of effectiveness was evaluated on the basis of PT values denoting persistent toxicity and $\mathrm{LT}_{50}$ values (Sarup et al., 1970). Thus these values can serve as ready recknor for quick selection of persistent pesticides. Under this background, the present investigation was planned to study the bioefficacy, persistence and residual toxicity of different insecticides against $A$. modicella infesting soybean. 


\section{Materials and Methods}

\section{Bio-efficacy of different insecticides against A. modicella infesting soybean}

The field experiment on bio-efficacy of different insecticides against $A$. modicella infesting soybean using variety MAUS-71 was conducted in RBD with eight treatments including untreated control replicated three times at the Research Farm of Department of Agril. Entomology, College of Agriculture, Latur (Vasantrao Naik Marathwada Krishi Vidyapeeth, Parbhani) (MS)-India during Kharif 2015. Soybean was grown with all recommended package of practices recommended by VNMKV, Parbhani for raising the crop except insect-pest management. The first application of insecticide spray was done at ETL. The observations on total number of $A$. modicella larvae were recorded on one meter row length from each treatment at three randomly selected places at one day before and 1, 3, 7 and 14 days after application of insecticides. The data on larval population were transformed into square root transformation before statistical analysis to know the significance of difference among different treatments. At maturity the crop was harvested and weight of grain per plot was recorded separated from each treatment. Plot wise yield was computed on hectare basis for statistical interpretation. The economics of the treatment was also computed based on grain yield and cost of protection. The incremental cost benefit ratio (ICBR) was computed based on cost of protection and gross profit. The data in respect of bio-efficacy and economics of different insecticides against $A$. modicella infesting soybean were statistically analyzed by standard 'analysis of variance'. The null hypothesis was tested by ' $F$ ' test of significance at 5 per cent level (Gomez and Gomez, 1984).
Persistence and residual toxicity of different insecticides against $A$. modicella infesting soybean

The toxicity of different insecticides was studied against third instar larvae of $A$. modicella at 1, 3, 7 and 14 days after application of insecticides. Due care was taken to cover the entire plant while application of insecticides. The required numbers of leaves receiving application of insecticides were tagged for investigations on residual toxicity of insecticides. The number of test insects used for the bioassay studies were ten for each treatment in each replication. The tagged leaves were brought into the laboratory at the prescribed day intervals. The treated leaves were kept into plastic containers separately. The stalk of leaves was covered with moistened cotton wool in order to retain their turgidity for 24 hours. Then the laboratory reared third instar larvae of A. modicella were released on treated leaves of soybean separately. The numbers of dead or moribund test insects were counted after 24 hours of exposure. Similarly control mortality of test insects was also observed by releasing them on untreated substrate of soybean plant.

\section{Correction on percentage mortality}

The observations on mortality of test insects were converted into percentage mortality. The average percentage mortality was calculated from the observations in 3 replications. The observations on percentage mortality thus obtained were corrected with Abbott's (1925) formula as follows.

$$
P=\frac{T-C}{100-C} \times 100
$$

Where as, $\mathrm{P}=$ Corrected percentage mortality, $\mathrm{T}=$ Percentage mortality in treatment, $\mathrm{C}=$ Percentage mortality in control. 


\section{$\mathbf{L T}_{50}$ values}

The values of $\mathrm{LT}_{50}$ (time required to give 50 per cent mortality) for different insecticides applied on soybean plants were calculated by using software of Probit analysis as suggested by Finney (1971).

\section{PT values}

The product (PT) of average residual toxicity (T) and the period (P) for which the toxicity persisted was used as an index of persistent toxicity. The values of corrected percentage mortalities at various specified periods were added. This sum was then divided by number of observations in order to obtain residual toxicity (T). The procedure followed by Saini (1959) and elaborated further by Pradhan (1967), Sarup et al., (1970) and; Kolhe et al., (2015) was utilized.

\section{Results and Discussion}

Effect of different insecticides on population of soybean leaf miner, $A$. modicella

Data pertaining to the effect of different insecticides on larval population of $A$. modicella infesting soybean after spray are presented in Table 1.

The results revealed that all the insecticides were found to be significantly superior over untreated control in reducing larval population of A. modicella at 1, 3, 7 and 14 days after application of insecticides.

At one day after spray, significantly minimum larval population of $A$. modicella was registered from the plots treated with chlorantraniliprole 0.004 per cent (1.11 per mrl) followed by emamectin benzoate 0.001 per cent (1.22 per mrl) and indoxacarb 0.010 per cent $(1.33$ per $\mathrm{mrl})$. All these treatments were statistically at par with each other. Subsequently effective treatments were quinalphos 0.050 per cent (2.11 larvae per $\mathrm{mrl}$ ), profenophos 0.100 per cent (2.22 larvae per $\mathrm{mrl})$, triazophos 0.050 per cent $(2.78$ larvae per mrl) and ethion 0.100 per cent (2.33 larvae per $\mathrm{mrl}$ ). At three days after spray, chlorantraniliprole 0.004 per cent $(1.22$ per mrl), emamectin benzoate 0.001 per cent (1.78 per mrl) and indoxacarb 0.010 per cent (1.88 per mrl) recorded equally effective treatments in lowering larval population of $A$. modicella. The next efficient treatments in minimizing larval population of leaf miner were quinalphos 0.050 per cent $(2.67$ per mrl), profenophos 0.100 per cent $(2.77$ per $\mathrm{mrl}$ ), triazophos 0.050 per cent (3.11 per $\mathrm{mrl}$ ) and ethion 0.100 per cent (3.33 per mrl).

At seven days after spraying, significantly least larval population of A. modicella was evidenced from the plots treated with chlorantraniliprole 0.004 per cent $(1.78$ per mrl) and emamectin benzoate 0.001 per cent (2.33 per mrl). Both these treatments were found to be statistically at par with each other. The subsequent order of effectiveness was indoxacarb 0.010 per cent (2.56 larvae per $\mathrm{mrl}$ ), quinalphos 0.050 per cent (2.89 larvae per $\mathrm{mrl}$ ), profenophos 0.100 per cent (3.22 larvae per mrl), triazophos 0.050 per cent (3.56 larvae per mrl) and ethion 0.100 per cent (3.78 larvae per mrl). At 14 days after spraying, chlorantraniliprole 0.004 per cent exhibited significantly lowest population of $A$. modicella (2.11 per mrl). However, emamectin benzoate 0.001 per cent $(2.67$ larvae per mrl) and indoxacarb 0.010 per cent (2.89 larvae per mrl) observed to be next effective treatments. However, quinalphos 0.050 per cent (3.33 larvae per $\mathrm{mrl}$ ), profenophos 0.100 per cent (3.44 larvae per $\mathrm{mrl}$ ), ethion 0.100 per cent (4.00 larvae per $\mathrm{mrl})$, and triazophos 0.050 per cent (4.22 larvae per mrl) were subsequently effective treatments. 
Table.1 Effect of different insecticides on larval population of A. modicella, grain yield and ICBR of soybean

\begin{tabular}{|c|c|c|c|c|c|c|c|}
\hline \multirow[t]{4}{*}{ Treatments } & \multicolumn{5}{|c|}{ Mean larval population of $A$. modicella per mrl } & \multirow{4}{*}{$\begin{array}{l}\text { Main } \\
\text { grain } \\
\text { yield } \\
\text { q/ha }\end{array}$} & \multirow[t]{4}{*}{ ICBR } \\
\hline & \multicolumn{5}{|c|}{$\mathrm{I}^{\text {st }}$ spray } & & \\
\hline & \multirow{2}{*}{$\begin{array}{c}\text { One day } \\
\text { before spray }\end{array}$} & \multicolumn{4}{|c|}{ Days after spraying } & & \\
\hline & & 1 & 3 & 7 & 14 & & \\
\hline $\begin{array}{l}\text { Profenophos } \\
0.100 \text { per cent }\end{array}$ & $\begin{array}{c}6.89 \\
(2.68)^{*}\end{array}$ & $\begin{array}{c}2.22 \\
(1.59)\end{array}$ & $\begin{array}{c}2.77 \\
(1.66)\end{array}$ & $\begin{array}{c}3.22 \\
(1.77)\end{array}$ & $\begin{array}{c}3.44 \\
(1.85)\end{array}$ & 20.46 & $1: 6.77$ \\
\hline $\begin{array}{l}\text { Triazophos } \\
0.050 \text { per cent }\end{array}$ & $\begin{array}{c}6.22 \\
(2.45)\end{array}$ & $\begin{array}{c}2.78 \\
(1.66)\end{array}$ & $\begin{array}{c}3.11 \\
(1.75)\end{array}$ & $\begin{array}{c}3.56 \\
(1.86)\end{array}$ & $\begin{array}{c}4.22 \\
(2.05)\end{array}$ & 20.96 & $1: 11.69$ \\
\hline $\begin{array}{l}\text { Quinalphos } \\
0.050 \text { per cent }\end{array}$ & $\begin{array}{c}5.89 \\
(2.42)\end{array}$ & $\begin{array}{c}2.11 \\
(1.43)\end{array}$ & $\begin{array}{c}2.67 \\
(1.62)\end{array}$ & $\begin{array}{c}2.89 \\
(1.68)\end{array}$ & $\begin{array}{c}3.33 \\
(1.82)\end{array}$ & 29.63 & $1: 19.72$ \\
\hline $\begin{array}{l}\text { Indoxacarb } \\
0.010 \text { per cent }\end{array}$ & $\begin{array}{c}6.22 \\
(2.49)\end{array}$ & $\begin{array}{c}1.33 \\
(1.14)\end{array}$ & $\begin{array}{c}1.88 \\
(1.36)\end{array}$ & $\begin{array}{c}2.56 \\
(1.59)\end{array}$ & $\begin{array}{c}2.89 \\
(1.69)\end{array}$ & 31.25 & $1: 11.24$ \\
\hline $\begin{array}{l}\text { Ethion } \\
0.100 \text { per cent }\end{array}$ & $\begin{array}{c}5.89 \\
(2.41)\end{array}$ & $\begin{array}{c}2.33 \\
(1.52)\end{array}$ & $\begin{array}{c}3.33 \\
(1.82)\end{array}$ & $\begin{array}{c}3.78 \\
(1.94)\end{array}$ & $\begin{array}{c}4.00 \\
(1.99)\end{array}$ & 16.43 & $1: 3.51$ \\
\hline $\begin{array}{l}\text { Chlorantraniliprole } \\
0.004 \text { per cent }\end{array}$ & $\begin{array}{c}6.67 \\
(2.57)\end{array}$ & $\begin{array}{c}1.11 \\
(1.05)\end{array}$ & $\begin{array}{c}1.22 \\
(1.09)\end{array}$ & $\begin{array}{c}1.78 \\
(1.33)\end{array}$ & $\begin{array}{c}2.11 \\
(1.45)\end{array}$ & 34.87 & 1:7.95 \\
\hline $\begin{array}{l}\text { Emamectin } \\
\text { benzoate } \\
0.001 \text { per cent }\end{array}$ & $\begin{array}{c}6.89 \\
(2.62)\end{array}$ & $\begin{array}{c}1.22 \\
(1.09)\end{array}$ & $\begin{array}{c}1.78 \\
(1.32)\end{array}$ & $\begin{array}{c}2.33 \\
(1.52)\end{array}$ & $\begin{array}{c}2.67 \\
(1.62)\end{array}$ & 31.55 & $1: 9.87$ \\
\hline Untreated Control & $\begin{array}{c}6.44 \\
(2.52)\end{array}$ & $\begin{array}{c}6.67 \\
(2.58)\end{array}$ & $\begin{array}{c}6.89 \\
(2.62)\end{array}$ & $\begin{array}{c}7.22 \\
(2.68)\end{array}$ & $\begin{array}{c}7.56 \\
(2.74)\end{array}$ & 12.09 & - \\
\hline S.E \pm & - & 0.07 & 0.07 & 0.08 & 0.05 & 0.02 & - \\
\hline C.D. at 5 per cent & NS & 0.23 & 0.21 & 0.24 & 0.15 & 0.08 & - \\
\hline C.V. & - & 8.76 & 7.20 & 7.71 & 4.61 & 0.61 & - \\
\hline
\end{tabular}

* Figures in parentheses are angular transformed values

N.S.: Non-significant 
Table.2 Persistence of different insecticides in/on leaves of soybean applied as first spray against third instar larvae of $A$. modicella

\begin{tabular}{|c|c|c|c|c|c|c|c|c|c|}
\hline \multirow[t]{2}{*}{ Insecticides } & \multicolumn{4}{|c|}{$\begin{array}{l}\text { Corrected percentage mortality after } \\
\text { different intervals (days) }\end{array}$} & \multirow[t]{2}{*}{$\mathbf{P}$} & \multirow[t]{2}{*}{$\mathbf{T}$} & \multirow[t]{2}{*}{ PT } & \multirow[t]{2}{*}{ R.E. } & \multirow[t]{2}{*}{ O.R.E. } \\
\hline & 1 & 3 & 7 & 14 & & & & & \\
\hline Profenophos 0.100 per cent & 85.76 & 67.88 & 51.70 & 10.51 & 53.96 & 14 & 755.47 & 1.10 & 5 \\
\hline Triazophos 0.050 per cent & 82.11 & 67.88 & 48.29 & 10.81 & 52.27 & 14 & 731.81 & 1.07 & 6 \\
\hline Quinalphos 0.050 per cent & 89.29 & 71.13 & 55.22 & 14.34 & 57.49 & 14 & 804.93 & 1.17 & 4 \\
\hline Indoxacarb 0.010 per cent & 89.29 & 75.05 & 55.22 & 14.34 & 58.47 & 14 & 818.65 & 1.19 & 3 \\
\hline Ethion 0.100 per cent & 78.58 & 64.34 & 44.88 & 7.17 & 48.74 & 14 & 682.39 & 1.00 & 7 \\
\hline Chlorantraniliprole 0.004 per cent & 94.46 & 82.73 & 62.84 & 21.52 & 65.39 & 14 & 915.46 & 1.34 & 1 \\
\hline Emamectin benzoate 0.001 per cent & 92.82 & 69.31 & 58.63 & 17.88 & 62.16 & 14 & 870.24 & 1.27 & 2 \\
\hline
\end{tabular}

Table.3 Relative efficacy of different insecticides against third instar larvae of A. modicella on soybean leaves applied as first spray

\begin{tabular}{|c|c|c|c|c|c|c|c|c|}
\hline \multirow[t]{2}{*}{ Insecticides } & \multicolumn{2}{|c|}{ Heterogeneity } & \multirow{2}{*}{$\begin{array}{c}\text { Regression Equation } \\
\qquad(y=\ldots \ldots)\end{array}$} & \multirow[t]{2}{*}{$\log \mathrm{LT}_{50} \pm \mathrm{S} . \mathrm{Em}$} & \multirow{2}{*}{$\begin{array}{l}\mathbf{L T}_{50} \\
\text { (days) }\end{array}$} & \multirow{2}{*}{$\begin{array}{l}\text { Fiducial Limit } \\
\text { (days) }\end{array}$} & \multirow[t]{2}{*}{ R.E. } & \multirow[t]{2}{*}{ O.R.E. } \\
\hline & d.f. & $\chi^{2}$ & & & & & & \\
\hline $\begin{array}{l}\text { Profenophos } \\
0.100 \text { per cent }\end{array}$ & 2 & 1.009 & $y=0.1311-1.7787 x$ & $0.7046 \pm 0.1318$ & 5.06 & $\begin{array}{c}1.09 \\
12.33\end{array}$ & 1.25 & 5 \\
\hline $\begin{array}{l}\text { Triazophos } \\
\text { 0.050 per cent }\end{array}$ & 2 & 0.996 & $y=-0.1065-1.6757 x$ & $0.6272 \pm 0.1377$ & 4.70 & $\begin{array}{c}1.07 \\
11.87\end{array}$ & 1.16 & 6 \\
\hline $\begin{array}{l}\text { Quinalphos } \\
\text { 0.050 per cent }\end{array}$ & 2 & 0.808 & $y=0.1661-1.8448 x$ & $0.7667 \pm 0.1303$ & 5.84 & $\begin{array}{c}1.17 \\
14.92\end{array}$ & 1.44 & 4 \\
\hline $\begin{array}{l}\text { Indoxacarb } \\
\text { 0.010 per cent }\end{array}$ & 2 & 0.897 & $y=0.1870-1.8899 x$ & $0.7809 \pm 0.1287$ & 6.03 & $\begin{array}{c}1.18 \\
15.26\end{array}$ & 1.49 & 3 \\
\hline $\begin{array}{l}\text { Ethion } \\
0.100 \text { per cent }\end{array}$ & 2 & 1.227 & $y=-0.0655-1.6542 x$ & $0.6065 \pm 0.1387$ & 4.04 & $\begin{array}{l}0.97 \\
9.48\end{array}$ & 1.00 & 7 \\
\hline $\begin{array}{l}\text { Chlorantraniliprole } \\
\text { 0.004 per cent }\end{array}$ & 2 & 0.379 & $y=0.2126-2.2456 x$ & $0.8914 \pm 0.1181$ & 7.78 & $\begin{array}{c}1.29 \\
19.52\end{array}$ & 1.92 & 1 \\
\hline $\begin{array}{l}\text { Emamectin benzoate } \\
0.001 \text { per cent }\end{array}$ & 2 & 0.656 & $y=0.2096-2.0192 x$ & $0.8383 \pm 0.1252$ & 6.89 & $\begin{array}{c}1.24 \\
17.68\end{array}$ & 1.70 & 2 \\
\hline
\end{tabular}


The results of present finding on the effectiveness of different insecticides against leaf miner are in conformity with those of Kothalkar et al., (2015) who revealed that emamectin benzoate $5 \mathrm{SG}$ at the rate of 0.002 per cent and triazophos $40 \mathrm{EC}$ at the rate of 0.06 per cent were proved to be significantly effective treatments in managing the soybean leaf miner. However, Dhurgude et al., (2015) and Shirale et al., (2010) noticed that triazophos 40 EC registered lowest larval population of leaf miner on soybean. According to Shali Raju et al., (2013) rynaxypyr $20 \mathrm{SC}$ (chlorantraniliprole) at the rate of $100 \mathrm{ml}$ per ha was significantly effective treatment against soybean defoliators and on par with commonly recommended insecticides viz. profenophos $50 \mathrm{EC}$ at the rate of $1250 \mathrm{ml}$ per ha, triazophos $40 \mathrm{EC}$ at the rate of $800 \mathrm{ml}$ per ha and quinalphos $25 \mathrm{EC}$ at the rate of $1500 \mathrm{ml}$ per ha and recorded less than 1 larva per mrl. While, Joshi and Patel (2011) reported that quinalphos 0.05 per cent, triazophos 0.06 per cent and emamectin benzoate at the rate of $5 \mathrm{~g}$ per 10 litre were most effective for the control of leaf miner (A. modicella) infesting soybean. Similarly, Mutkule et al., (2010) investigated that emamectin benzoate and quinalphos were effective against groundnut leaf miner.

Effect of different insecticides on grain yield and incremental cost benefit ratio (ICBR) of soybean

The results in respect of effect of different insecticides on grain yield and ICBR of soybean are presented in Table 1.

The data on grain yield of soybean revealed that all the treatments were statistically significant in increasing grain yield over untreated control. The grain yield of soybean due to different treatments varied from 12.09 to $34.87 \mathrm{q}$ per ha. The significantly highest grain yield of soybean was registered in chlorantraniliprole 0.004 per cent $(34.87$ q per ha) which was followed by emamectin benzoate 0.001 per cent (31.55 q per ha), indoxacarb 0.010 percent (31.25 q per ha), quinalphos 0.050 per cent $(29.63$ q per ha), triazophos 0.050 per cent (20.96 q per), profenophos 0.100 per cent (20.46 q per ha) and ethion 0.100 per cent (16.43 q per ha). The result of present investigation are in agreement with the findings of Patil et al., (2014) who reported that significantly highest seed yield of soybean (19.88 q per ha) was obtained in chlorantraniliprole (30 g a.i. per ha). Kothalkar et al., (2015) revealed that emamectin benzoate $5 \mathrm{SG}$ at the rate of 0.002 per cent + triazophos $40 \mathrm{EC}$ at the rate of 0.06 per cent, emamectin benzoate $5 \mathrm{SG}$ at the rate of 0.002 per cent, triazophos $40 \mathrm{EC}$ at the rate of 0.06 per cent and flubendiamide $20 \mathrm{WG}$ at the rate of 0.01 per cent + triazophos $40 \mathrm{EC}$ at the rate of 0.06 per cent obtained comparatively highest yield.

The data on ICBR evidenced that all the insecticidal treatments were economical and most remunerative. Among all the treatments, highest incremental cost benefit ratio (1:19.72) was achieved by quinalphos 0.050 per cent which was followed by triazophos 0.050 per cent (1:11.69), indoxacarb 0.005 per cent (1:11.24), emamectin benzoate 0.001 per cent (1:9.87), chlorantraniliprole 0.004 per cent (1:7.95), profenophos 0.100 per cent (1:6.77) and ethion 0.100 per cent (1:3.51). These results are analogous to the findings of Wagh et al., (2015) who documented that highest cost benefit ratio of 1:6.43 was observed in profenophos 0.100 EC followed by quinalphos (1:6.24) in soybean. Kothalkar et al., (2015) revealed that emamectin benzoate $5 \mathrm{SG}$ at the rate of 0.002 per cent + triazophos $40 \mathrm{EC}$ at the rate of 0.06 per cent, emamectin benzoate $5 \mathrm{SG}$ at the rate of 0.002 per cent, triazophos $40 \mathrm{EC}$ at the rate of 0.06 per cent and flubendiamide $20 \mathrm{WG}$ at the rate 
of 0.01 per cent + triazophos $40 \mathrm{EC}$ at the rate of 0.06 per cent were obtained comparatively highest ICBR. Raghuvanshi et al., (2014) observed highest ICBR (1:9.6) in triazophos; however, indoxacarb and emamectin benzoate noticed ICBR of 1: 4.5 and 1: 4.1, respectively.

\section{Residual toxicity of different insecticides against soybean leaf miner, $A$. modicella}

The data on the average percentage mortality of third instar larvae A. modicella on soybean leaves against spray recorded at 1, 3, and 7 and 14 days intervals are presented in Table 2.

The result of spray evidenced that chlorantraniliprole 0.004 per cent and emamectin benzoate 0.001 per cent concentrations showed comparatively high percentage mortality of third instar larvae of $A$. modicella to the tune of 65.39 and 62.16 per cent, respectively at 14 days after spraying. On the basis of PT values the descending order of persistent toxicity was chlorantraniliprole 0.004 per cent (915.46) > emamectin benzoate 0.001 per cent $(870.24)>$ indoxacarb 0.010 per cent $(818.65)>$ quinalphos 0.050 per cent $(804.93)$ $>$ profenophos 0.100 per cent (755.47) > triazophos 0.050 per cent $\quad$ (731.81)> ethion 0.100 per cent (682.39).

The data on $\mathrm{LT}_{50}$ values of insecticides against third instar larvae of A. modicella on soybean leaves receiving spray are presented in Table 27 and depicted in Fig 26.

The data revealed that chlorantraniliprole 0.004 per cent exhibited highest $\mathrm{LT}_{50}$ value (7.78 days) against third instar larvae of $A$. modicella on soybean leaves receiving first application of insecticides followed by emamectin benzoate 0.001 per cent (6.89 days), indoxacarb 0.010 per cent (6.03 days), quinalphos 0.050 per cent (5.84 days), profenophos 0.100 per cent (5.06 days), triazophos 0.050 per cent (4.70 days) and ethion 0.100 per cent (4.04 days).

Thus, it indicates that chlorantraniliprole 0.004 per cent followed by emamectin benzoate 0.001 per cent illustrated higher residual toxicity to third instar larvae $A$. modicella as compare to other insecticides. These results are analogous to the findings of Kolhe et al., (2015) who revealed that effective treatments in terms of PT and $\mathrm{LT}_{50}$ values were by quinalphos 0.07 per cent and emamectin benzoate 0.002 per cent. However, Joshi and Patel, (2011) indicated that quinalphos 0.05 per cent, triazophos 0.06 per cent and emamectin benzoate at the rate of 5 gm per 10 litre were efficacious insecticides registered higher mortality of leaf miner on soybean. Jain et al., (2012) revealed that profenophos and ethion persisted more than 11 days on leaves and 9 days on pods of soybean.

In conclusion the overall results proved that chlorantraniliprole 0.004 per cent was the most efficacious insecticide against $A$. modicella infesting soybean followed by emamectin benzoate 0.001 per cent and indoxacarb 0.010 per cent. Similarly, the higher residual toxicity was exhibited by these insecticides against third instar larvae of A. modicella on soybean.

\section{References}

Abbott, W.S. 1925. A method of computing the effectiveness of insecticide. J. Econ. Entmol., 18 (4): 265-267.

Agarwal, D.K., Billore, S.D., Sharma, A.N., Dupare, B.U. and Srivastava, S.K. 2013. Soybean: introduction, improvement, and utilization in India-problems and prospects. Agric. Res., 2 (4): 293-300.

Ahirwar, K.C., Marabi, R.S. and Bhowmick, A.K. 2014. Population dynamics of major insect pests and seed yield of 
soybean. Ann. Pl. Prot. Sci., 22 (1): 5659.

Bhamare, V.K., Phatak, S.V., Kumbhar, S.C. and Bade, A.S. 2018. Influence of ambient weather on the incidence of major insect-pests of sole soybean and soybean intercropped with pigeonpea. $J$. Entomol. Zool. Stud., 6 (5): 437-443.

Dhurgude, S.S., Bhosle, B.B., Patait, D.D., Bhede, B.V., Zawar, P.R. and Badgujar, A.G. 2015. Efficacy of different insecticides against Leaf miner Aproaerema modicella, (Deventer) on Soybean. J. Entomol. Res., 39 (4): 365368.

Du Plessis and Van Denberg, J. 2011. Biology and management of groundnut leafminer. African Crop Science Conference Proceedings, 10: 169-172.

Dwevedi, A. and Kayastha, A.M. 2011. SOYBEAN: A multifaceted legume with enormous economic capabilities. In Soybean - Biochemistry, Chemistry and Physiology Edited by Tzi Bun Ng. Published by InTech Janeza Trdine 9, 51000 Rijeka, Croatia: 165-188.

Finney, D.J. 1971. Probit Analysis, Cambridge University Press, Cambridge: 333.

Gomez, K.A. and Gomez, A.A. 1984. "Statistical procedures for agricultural and research" (2 edn.). A John Wiley and Sons Intersciences Publications. An International Res. Institute, Philippines. 680.

Jain, D.K., Chechani, V.K. and Gupta, C.L. 2012. Studies on comparative persistence and dissipation of residues of insecticides on soybean. Pestology, 36 (6): $42-44$.

Joshi MD and Patel VN. 2011. Effectiveness of Beauveria bassiana on soybean leaf miner, Aproaerema modicella Deventer. Leg. Res. 34 (1): 73-74.

Kolhe, B.D., Bhamare, V.K., Sawant, C.G., Naik, M.N. 2015. Residual toxicity of different insecticides against groundnut leaf miner Aproaerema modicella Deventer. Res. J. Agril. Sci., 6 (6): 1271-1276.

Kothalkar, R.R., Thakare, A.Y. and Salunke, P.B. 2015. Effect of newer insecticides in combination with Triazophos against insect pest of soybean. Agric. Sci. Digest., 35 (1): 46-50.

Lawrence, K.A. 2011. Soybean: Africa's potential Cinderella food crop. In Soybean - Biochemistry, Chemistry and Physiology Edited by Tzi Bun Ng. Published by InTech Janeza Trdine 9, 51000 Rijeka, Croatia: 137-150.

Mutkule, D.S., Jagtap, PK, Deshpande, S. and Deshpande, K.A. 2010. Efficacy of some newer insecticides against defoliators and leaf miner pests on groundnut. Pestology, 34 (4): 20-21.

Patil, M.U., Kulkarni, A.V. and Gavkare, O. 2014. Evaluating the efficacy of novel molecules against soybean defoliators. The Bioscan, 9 (1): 577-580.

Phatak, S.V. and Bhamare, V.K. 2019. Lifetables of Aproaerema modicella Deventer on soybean and soybean intercropped with pigeonpea. Indian $J$. Entomol., 81 (2): 255-260.

Pradhan, S. 1967. Strategy of integrated pest control. Indian J. Entomol., 29 (1): 105122.

Raghuvanshi, S., Bhadauria, N.S. and Singh, P. 2014. Efficacy of Insecticides against Major Insect Pests of Soybean. Indian. J. Com., 7 (3): 191193.

Rawat, R.R. and Kapoor, R.H. 1968. Arthropod pest of soybean in MP conference on soybean production and marketing. September 20-23. Proceeding J.N.J.K.V., Jabalpur.; 62-65.

Saini, M.L. 1959. Bioassay of persistence of spray residues on leaf surface of maize using just hatched larvae of Chilo zonellus (Swinhoe) as test insect. Assoc. 
I.A.R.I. Thesis, Indian Agricultural Research Institute, New Delhi (Unpublished).

Sarup, P., Singh, D.S., Amarpuri, S. and Rattan, Lal. 1970. Persistent and relative residual toxicity to some important pesticides to the adults of sugarcane leaf-hopper, Pyrilla perpusilla Walker (Lophopidae: Homoptera). Indian J. Entomol., 32 (3): 256-267.

Shali Raju, G., Khandwe, N. and Sharma, S. 2013. Efficacy of insecticides against defoliators and stem borers of soybean. Indian J. Entomol., 13 (2): 250-253.

Sharma, A.N., Gupta, G.K., Verma, R.K., Sharma, O.P., Bhagat, S., Amaresan, N., Saini, M.R., Chattopadhyay, C., Sushil, S.N., Asare, R., Kapur, K.S., Satygopal, K., Jeyakumar, P. 2014. Handbook of integrated pest management package for soybean, NCIPM, New Delhi. 1-2.

Shetgar, S.S. and Thombre, U. T. 1984. Occurance of natural enemies on soybean leaf miner and relative susceptibility of some varities to its attacks. J. Maharashtra Agril. University, 9 (2): 218-219.

Shirale, D., Patil, M. and Bidgire, U. 2010. Field evaluation of bio pesticides and synthetic insecticide against leaf miner, Aproaerema modicella population in soybean. J. Biopesticide, 3 (3): 358-360.

Singh, O.P. and Singh, K.J. 1990. Insect pest of soybean and their management. Indian farming, 39 (10): 9-14.

SOPA, 2020. http://www.sopa.org/indiaoilseeds-area-production-and productivity/.

USDA. 2019 https://fdc.nal.usda.gov/fdcapp.html\#/food-details/174270/ nutrients.

USDA. 2020. World Agricultural Production, United States Department of Agriculture Foreign Agricultural Service Circular Series WAP 11-20 November 2020.

Wagh, G.V., Deotale, R.O., Lavhe, N.V., Jiotode, D.J. and Patil, K.A. 2015.Validation of different insecticides against defoliator on soybean. Pestology, 39 (5): 35-40.

\section{How to cite this article:}

Bhamare, V. K., G. R. Wahekar, D. R. Bankar, B. A. Thakre, P. B. Hajare, R. S. Mahajan and More, A. S. 2021. Bio-efficacy, Persistence and Residual Toxicity of Different Insecticides against Soybean Leaf Miner Aproaerema modicella (Deventer) Infesting Soybean. Int.J.Curr.Microbiol.App.Sci. 10(01): 3262-3271. doi: https://doi.org/10.20546/ijcmas.2021.1001.380 